\section{Effect of Planting Date on Vegetable Amaranth Leaf Yield, Plant Height, and Gas Exchange}

\author{
W.F. Whitehead ${ }^{1}$, J. Carter, and B.P. Singh \\ Agricultural Research Station, Fort Valley State University, Fort Valley, \\ GA 31030-4313
}

\section{Additional index words. Amaranthus tricolor}

\begin{abstract}
Field studies were conducted during 1992 and 1993 to determine the effect of six monthly planting dates from April to September on gas exchange, plant height, and leafy fresh and dry yields of vegetable amaranth (Amaranthus tricolor L.). Vegetative growth was satisfactory for May to August planting. Seeds planted in April failed to germinate due to low soil temperatures. Plant growth was significantly reduced in the September planting possibly due to low fall temperatures and shortened day length. Soil and air temperatures $25^{\circ} \mathrm{C}$ or higher promoted optimal stand establishment and growth. The vegetative growth of June seeded amaranth took place during the warmest part of the summer and as a result had maximum $\mathrm{CO}_{2}$ exchange rate (CER), plant height, and leafy fresh and dry yields. The relationship between planting date and CER, transpiration rate $(E)$, stomatal conductance $\left(\mathrm{g}_{\mathrm{s}}\right)$, plant height, and leafy fresh and dry yields was quadratic, while a cubic equation provided best fit between the planting date and internal leaf $\mathrm{CO}_{2}$ concentration $\left(\mathrm{C}_{\mathrm{i}}\right)$. The results suggest that it is possible to stagger the planting of Amaranthus tricolor in the southeastern United States to assure availability of fresh leafy greens throughout the summer. However, the crop produces maximum leaf biomass when grown during the warmest part of the summer.
\end{abstract}

A profitable market has developed in the recent years for ethnic vegetables due to the influx of people from different parts of the world to the United States. Ethnic vegetables are also commonly grown in the home gardens of new immigrants. Some of these vegetables have the potential for wider acceptance due to their high nutritive value or as a seasonal substitute for a vegetable commonly grown in the United States.

Amaranth (Amaranthus sp.) is a common leafy vegetable in Asia, West Africa, and the Caribbean (Stallknecht and Schultz-Schaeffer, 1993). It has flavor similar to spinach (Spinacia oleraceae L.), but unlike spinach thrives in hot weather (Makus and Davis, 1984). Amaranth leaves are rich in iron, vitamin $\mathrm{A}$ and $\mathrm{C}$, minerals, and protein (Makus, 1990a; Rangarajan and Kelly, 1994; Segura-Nieto et al., 1994; Teutonico and Knorr, 1985). Thus, amaranth not only has an existing ethnic market but also a sizeable potential market among other American consumers seeking a fresh leafy vegetable during the summer months.

Amaranth is an annual $\mathrm{C}_{4}$ plant that grows best at warm temperatures and high light intensities (El-Sharkawy et al., 1968). Most of the amaranth consumed as leafy greens belongs to the species A. tricolor and A. dubius (National Research Council, 1984; Stallknecht and Schultz-Schaeffer, 1993). The plants are short in stature with wide leaves and small inflorescence (Huang, 1980). Some amaranth

Received for publication 22 Aug. 2001. Accepted for publication 7 Jan. 2002.

${ }^{1}$ To whom reprint request should be addressed. Email:whitehew@mail.fvsu.edu cultivars require short day for blooming (Grubben, 1977; Sawhney et al., 1980). Several studies suggest that the climate of the southern United States is suitable for the production of amaranth leafy greens (Igbokwe et al., 1988; Makus, 1989, 1990b; Sealy et al., 1990).

Research on cultural practices, such as planting date, population density, fertilization, and irrigation, is needed to successfully produce amaranth in the South. The knowledge of the effect of various cultural practices on the physiology, growth, and development of amaranth is essential to select appropriate cultural practices. Therefore, this study was initiated to investigate the effect of different dates of planting on the leaf $\mathrm{CO}_{2}$ and moisture exchange rates, plant height, and leafy fresh and dry yields of amaranth.

\section{Materials and Methods}

This study was conducted in 1992 and 1993 at the Fort Valley State Univ. Agricultural Research Station, Fort Valley, Ga., located at $32^{\circ} 34^{\prime} \mathrm{N}, 83^{\circ} 52^{\prime} \mathrm{W}$. Soil type at the experimental site was Dothan sandy loam (fine, loamy, siliceous, thermic, Plinthic Paleudult).

An amaranth genotype, PI 604669, belonging to species A. tricolor was used in the experiment. Plots consisted of four rows planted in the east-west direction. Rows were spacings of $0.92 \mathrm{~m}$ and $10 \mathrm{~cm}$, respectively. Soil was prepared to fine tilth and the seeds were planted on a firmed bed at a depth of 1$2 \mathrm{~cm}$. Seeds were planted both years on six dates: 12 Apr., 12 May, 15 June, 14 July, 15 Aug., and 14 Sept. The six planting date treat$6.1 \mathrm{~m}$ long with between- and within-row ments were arranged in a randomized complete block design and replicated four times. Fertilization, weed and insect control protocols comparable to other leafy greens were followed. Plots were irrigated after planting and $50 \mathrm{~mm}$ water was applied subsequently during periods of low rainfall with a reel rain gun.

The gas-exchange data were recorded only on amaranth planted May through August. Lack of plants and small size of leaves precluded measurements on April and September planting, respectively. Gas exchange parameters, viz., transpiration $\left(\mathrm{E}, \mathrm{mmol} \cdot \mathrm{m}^{-2} \cdot \mathrm{s}^{-1}\right), \mathrm{CO}_{2}$ exchange rate $\left(\mathrm{CER}, \mu \mathrm{mol} \cdot \mathrm{m}^{-2} \cdot \mathrm{s}^{-1}\right)$, stomatal conductance $\left(\mathrm{g}_{\mathrm{s}}, \mathrm{mmol} \cdot \mathrm{m}^{-2} \cdot \mathrm{s}^{-1}\right)$ and internal leaf $\mathrm{CO}_{2}$ concentration $\left(\mathrm{C}_{\mathrm{i}}, \mu \mathrm{L} \cdot \mathrm{L}^{-1}\right)$ were recorded 2-3 d prior to harvest. Measurements were recorded by a portable steady-state infrared gas-exchange system (Analytical Development, Huddleston, England). The newest fully expanded leaves on five randomly selected yield row plants were used to obtain nondestructive gas-exchange readings. Data were collected between 0900 and $1300 \mathrm{HR}$, when photosynthetic active radiation ranged between 1162 and $1605 \mu \mathrm{mol} \cdot \mathrm{m}^{-2} \cdot \mathrm{s}^{-1}$ and ambient temperature ranged between $25-30^{\circ} \mathrm{C}$.

Prior to harvest, plant height of five random plants in the two middle rows was measured. Plants were harvested $40 \mathrm{~d}$ from planting and leafy yield was estimated from a 4.6$\mathrm{m}$ section of the two middle rows. Plants were weighed after harvest for the fresh weight and dried at $70{ }^{\circ} \mathrm{C}$ to a constant weight for dry weight determination.

The rainfall, air temperature and soil temperature data during the growing season were obtained. Air and soil temperatures were measured at $1.5 \mathrm{~m}$ above ground and $5.1 \mathrm{~cm}$ below ground, respectively.

All data were subjected to analysis of variance. Regression analyses were performed by Proc GLM procedure (SAS Institute, 1988). Regression equations were selected on the best and most significant $(P \leq 0.01$ for $|\mathrm{T}|)$ regression parameters with highest coefficient of determination $\left(r^{2}\right)$.

\section{Results and Discussion}

Weather. Total rainfall during 1992 and 1993 growing seasons were 661 and $365 \mathrm{~mm}$, respectively (Fig. 1). At no time during the two growing seasons were plants under moisture stress, since irrigation was applied during periods of low rainfall. The range of the 2-year mean soil temperature was from $16.4^{\circ} \mathrm{C}$ in the first 2 weeks of April to $31.4^{\circ} \mathrm{C}$ in the last 2 weeks of July (Fig. 2). The 2-year mean air temperature ranged from $14.5^{\circ} \mathrm{C}$ in the first 2 weeks of April to $28.5^{\circ} \mathrm{C}$ in the last 2 weeks of July. The growing season in 1993 was warmer than 1992.

Stand establishment. Amaranth planted on 12 Apr. did not germinate, suggesting that the soil temperatures of 18 to $22.3^{\circ} \mathrm{C}$ during the period were not conducive for the germination process. Seeds germinated satisfactorily in May and subsequent planting dates when the soil temperature had reached above $25^{\circ} \mathrm{C}$. 


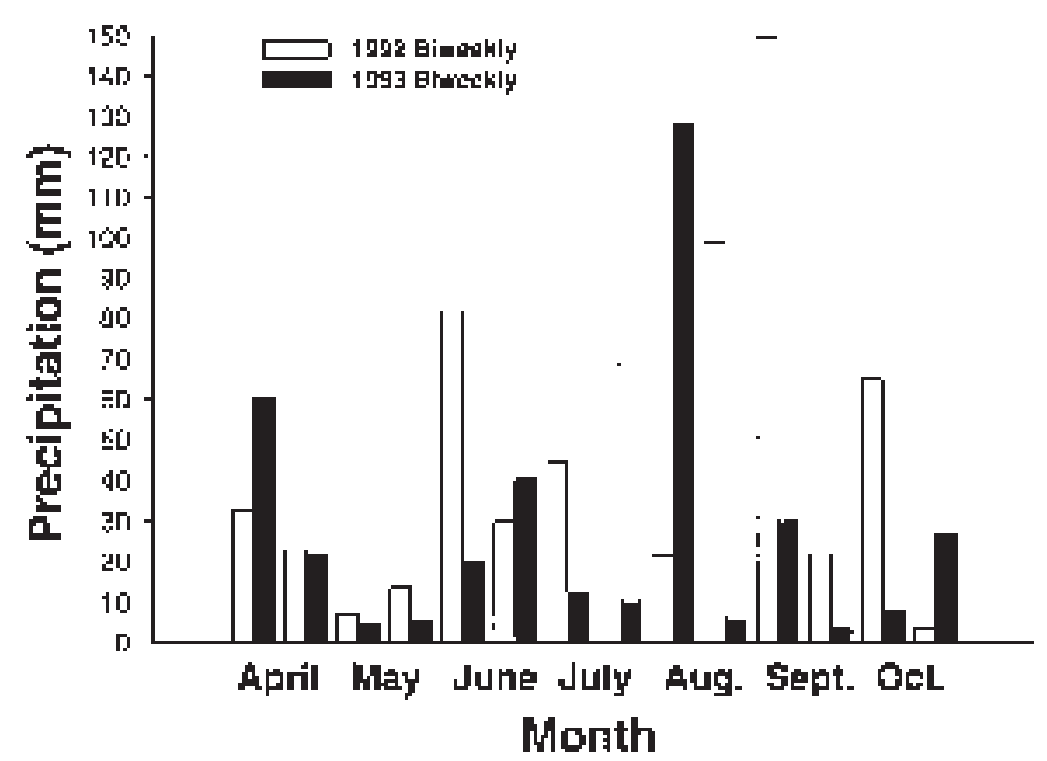

Fig. 1. Biweekly rainfall from April to October for 1992 and 1993.
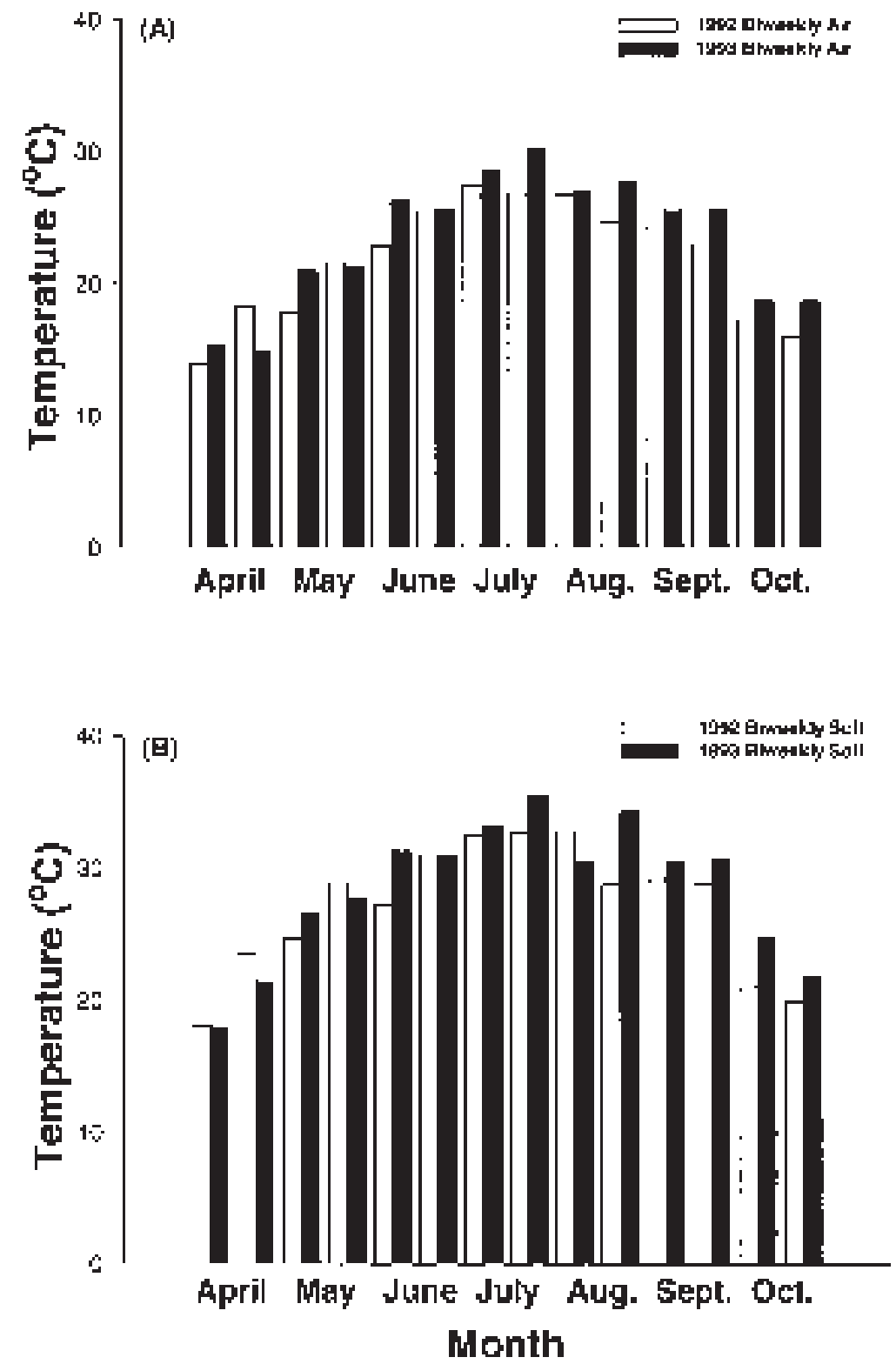

Fig. 2. Biweekly air and soil temperature from April to October for 1992 and 1993. 

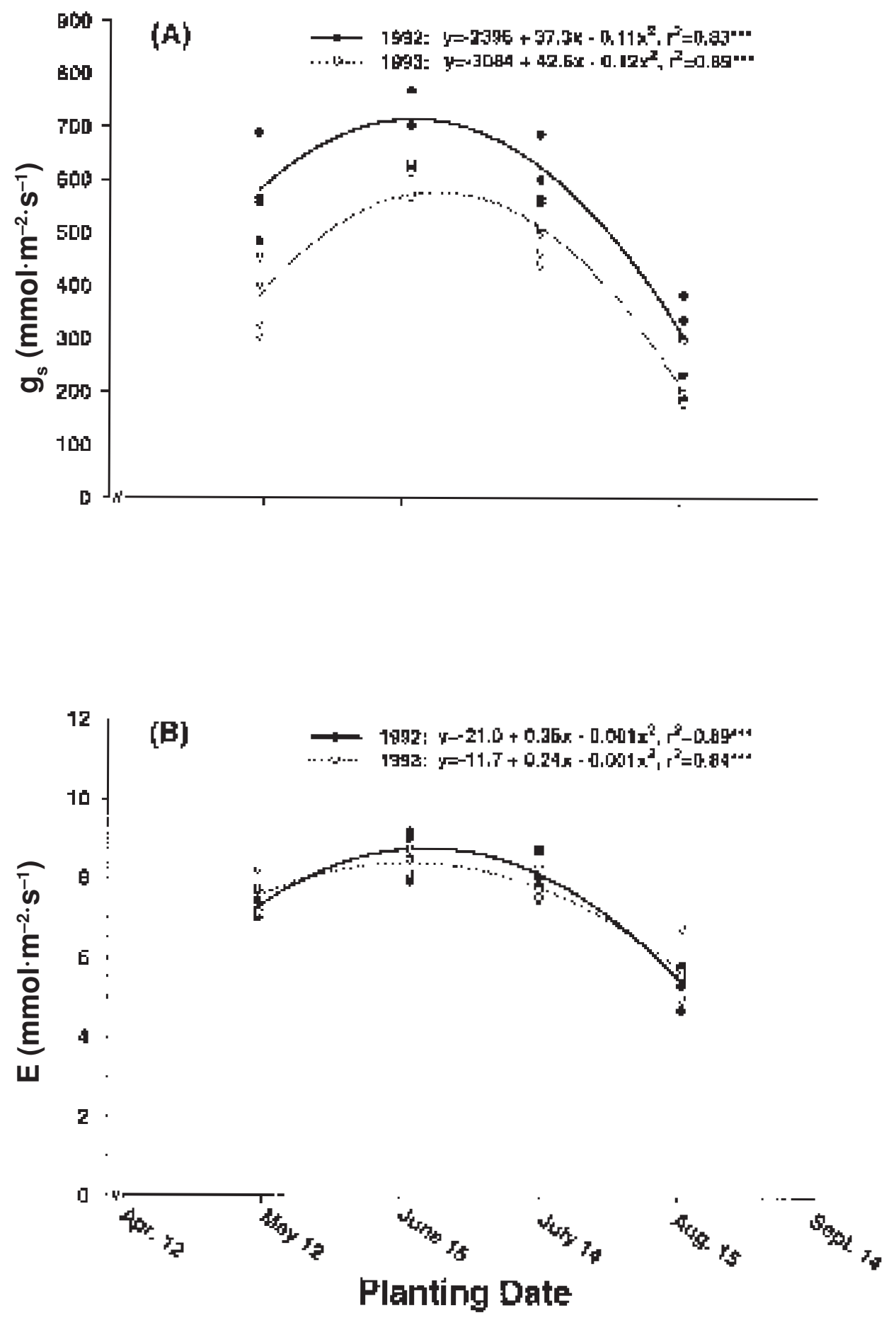

Fig. 3. Response of vegetable amaranth stomatal conductance $\left(\mathrm{g}_{\mathrm{s}}\right)$ and transpiration (E) to four planting dates. ${ }^{* * * * *}$ Significant at $P \leq 0.01$ and 0.001 , respectively.

Putnam (1990) opined that the amaranth seed germination was primarily controlled by Soil temperature. Myers (1996) found that temperatures at or above $24^{\circ} \mathrm{C}$ day/21 ${ }^{\circ} \mathrm{C}$ night were needed for optimum grain amaranth germination in controlled-environment tests. Webb et al. (1987) noted amaranth germination rate increasing with the soil temperatures on a thermogradient plate and 21.3 to $33.8^{\circ} \mathrm{C}$ was the optimum temperature range for seedling emergence. Haas and Schauer (1985) reported that amaranth species and cultivars differed in soil temperature requirements for germination. However, best results for most species and cultivars were obtained when seeds were planted in warm soil.

There was no problem in seedling establishment in May through August planting. But, September planting exhibited poor seedling growth. The environmental conditions for the growth of these seedlings were probably not optimal. The day length had become short during October and the mean air temperature had declined to $18^{\circ} \mathrm{C}$.
Gas-exchangerates. The amaranth E, CER, and $g_{s}$ differed significantly between 1992 and 1993 and thus the data were analyzed separately by year. There was no gas exchange $x$ year variation for $\mathrm{C}_{\mathrm{i}}$ and data from both years were pooled for analysis.

The relationship between $\mathrm{E}, \mathrm{g}_{\mathrm{s}}$, and CER to planting date was quadratic (Figs. 3 and 4). The mean coefficients of determination $\left(r^{2}\right)$ for $E, g_{s}$, and CER with the date of planting were $0.86,0.86$, and 0.76 , respectively. The results suggested that the date of planting 

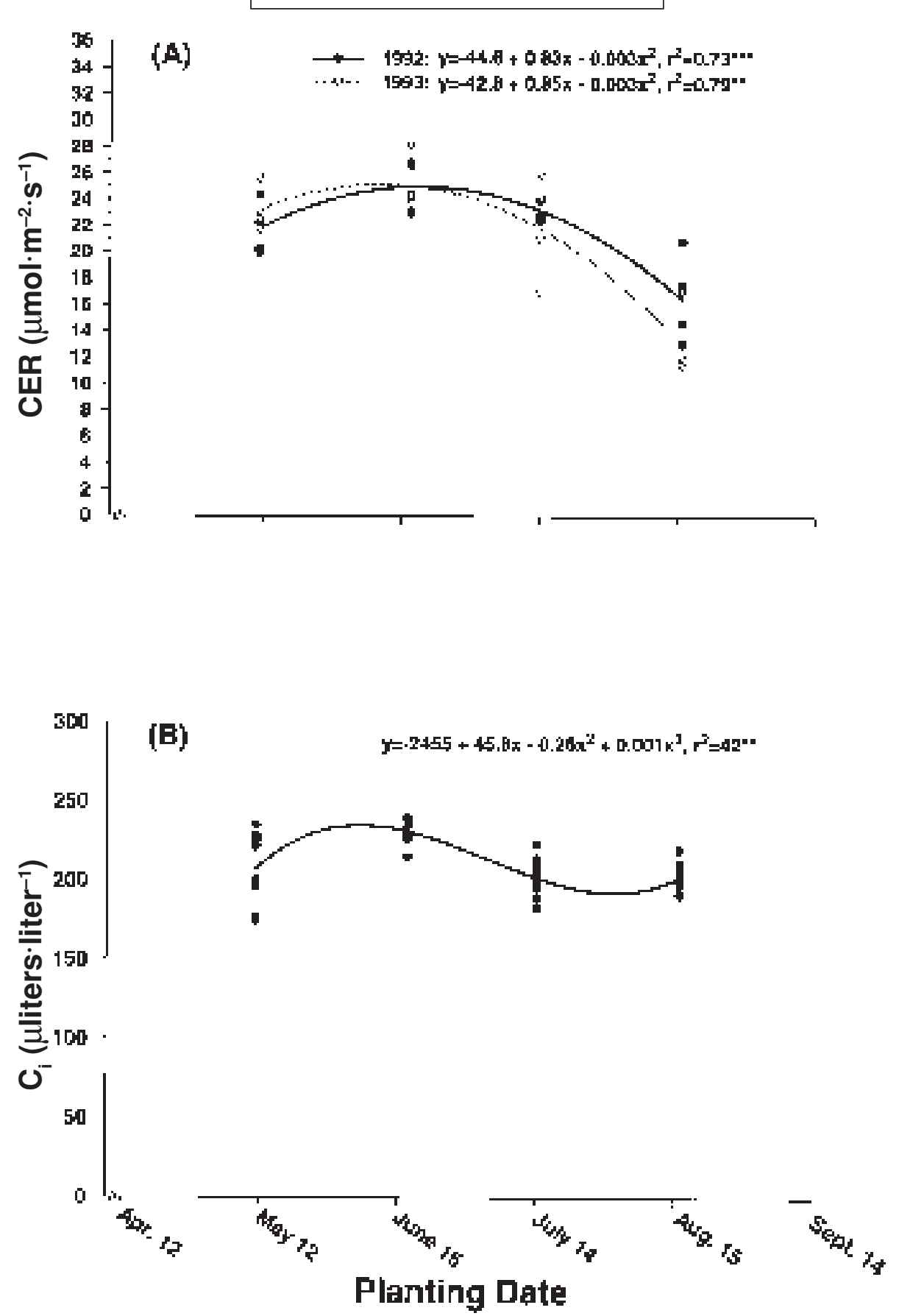

Fig. 4. Response of vegetable amaranth $\mathrm{CO}_{2}$ exchange rate (CER) and internal leaf $\mathrm{CO}_{2}$ concentration $\left(\mathrm{C}_{\mathrm{i}}\right)$ to four planting dates. (1992 and 1993 data combined for $\left.\mathrm{C}_{\mathrm{i}}\right)^{* * * * *}$ Significant at $P \leq 0.01$ and 0.001 , respectively.

greatly influenced the stomatal conductance, water vapor exchange, and $\mathrm{CO}_{2}$ exchange in the amaranth plant. A cubic model provided best fit for the regression of planting date on $\mathrm{C}_{\mathrm{i}}$ with a modest $r^{2}$ value of 0.42 . The ranges for $\mathrm{E}$, $\mathrm{g}_{\mathrm{s}}, \mathrm{CER}$, and $\mathrm{C}_{\mathrm{i}}$ were 5.5 to $8.5 \mathrm{mmol} \cdot \mathrm{m}^{-2} \cdot \mathrm{s}^{-1}$, 262.4 to $671.2 \mathrm{mmol} \cdot \mathrm{m}^{-2} \cdot \mathrm{s}^{-1}, 14.8$ to 25.1 $\mu \mathrm{mol} \cdot \mathrm{m}^{-2} \cdot \mathrm{s}^{-1}$, and 202.2 to $231.3 \mu \mathrm{L} \cdot \mathrm{L}^{-1}$, respectively. All gas-exchange parameters were maximum in the June planting. The August planting had minimum $\mathrm{E}, \mathrm{g}_{\mathrm{s}}, \mathrm{CER}$, while $\mathrm{C}_{\mathrm{i}}$ was lowest in July planting.

The above results suggest that the rate of gas exchange was dependent upon the air temperature. The measurements for the June planting were taken before harvest in July when air temperatures were highest, thus prompting maximum gas exchange. In redroot pigweed (A. retroflexus L.), a species related to amaranth, Chu et al. (1978) found similar photosynthetic response to temperature with the peak rate at $30^{\circ} \mathrm{C}$.

Plant height and leafy fresh and dry yields. Planting dates significantly affected plant height and leafy fresh and dry yields (Fig. 5). Plant height ranged from 7.0 to $49.0 \mathrm{~cm}$ with the tallest plants produced from the mid-June planting. Regression of plant height on planting dates was quadratic. Highest leafy fresh yield (12.3 Mg.ha' $\mathrm{h}^{-1}$ ) and dry yield (1.24 $\mathrm{Mg} \cdot \mathrm{ha}^{-1}$ ) were produced by the June planting, while lowest leafy fresh yield $\left(0.7 \mathrm{Mg} \cdot \mathrm{ha}^{-1}\right)$ and dry yield $\left(0.15 \mathrm{Mg} \cdot \mathrm{ha}^{-1}\right)$ resulted from the September planting. The relationships of leafy fresh and dry yields with planting date were also quadratic.

The highest yields obtained in this study compare favorably with those reported by Campbell and Abbott (1982), Makus (1984), and Makus and Davis (1984).

The vegetative growth of amaranth can be affected by temperature and day length. Seeds planted in June produced most vegetative matter because they developed during the warmest summer month of July. Other reports also suggest high daily temperatures for maximum amaranth vegetative growth (ElSharkawy et al., 1968; NRC, 1984). Grubben (1980) reported rapid growth and high yields of amaranth at $30-35^{\circ} \mathrm{C}$. The plant height and leafy fresh and dry yields of amaranth in 1993 

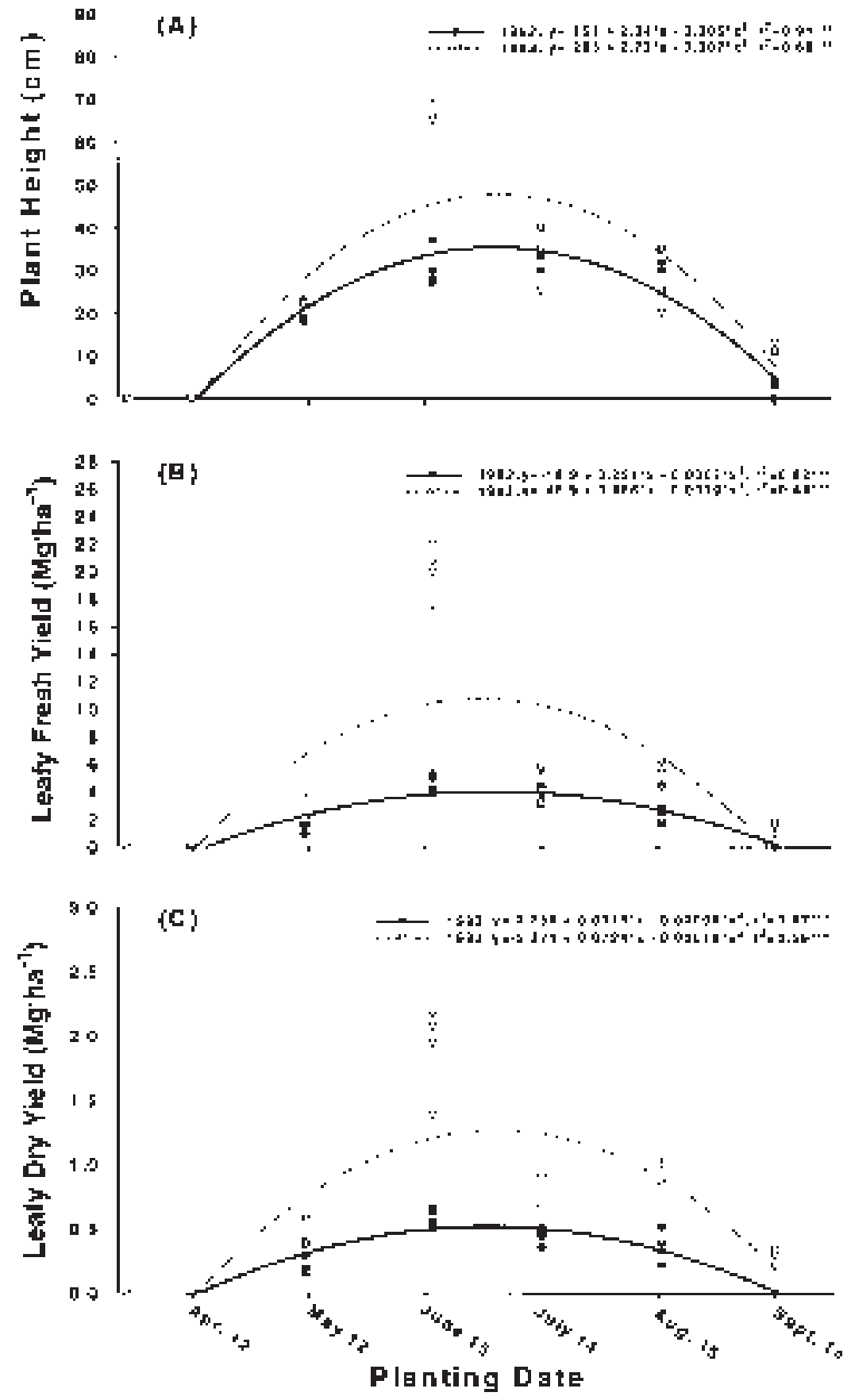

Fig. 5. Response of vegetable amaranth plant height, leafy fresh and dry yields to six planting dates. ${ }^{* * *}$ Significant at $P \leq 0.001$.

were significantly greater than 1992 . This was particularly true for the June planting. The growth difference between the 2 years was attributed to the warmer growing season during 1993 than 1992.

The low leaf yield in September planting could have resulted from a combination of low temperature and short day length during the growth period.

\section{Conclusions}

The study shows that Amaranthus tricolor can be grown successfully as a summer leafy vegetable in the southeastern United States. It can be direct seeded in Georgia from midMay to mid-August for this purpose. However, the maximum leafy greens yield is obtained when the vegetative growth takes place during the warmest part of the summer, which coincided with the June planting in Georgia. Mean daily soil temperatures at or above 25 ${ }^{\circ} \mathrm{C}$ are needed for maximum amaranth seed germination. Mean daily air temperatures in the $28-30^{\circ} \mathrm{C}$ range produce maximum leafy yield. The rate of photosynthesis is also highest at $28-30{ }^{\circ} \mathrm{C}$. The vegetative growth of amaranth is greatly reduced under decreasing day length and mean daily air temperatures declining to $18^{\circ} \mathrm{C}$.
Campbell, T.A. and J.A. Abbott. 1982. Field evaluation of vegetable amaranth (Amaranthus spp.). HortScience 17:407-409.

Chu, C.C., P.M. Ludford, J.L. Ozbun, and R.D. Sweet. 1978. Effects of temperature and competition on the establishment and growth of redroot pigweed and lambsquarters. Crop Sci. 18:308-310.

El-Sharkawy, M.A., R.S. Loomis, and W.A. Williams. 1968. Photosynthetic and respiratory exchanges of carbon dioxide by leaves of the grain amaranth. J. Appl. Ecol. 15:243-251.

Grubben, G.J.H. 1977. Leaf vegetables, p. 91-110. In: H.D. Tindall and J.T. Williams (eds.). Tropical vegetables and their genetic resources. Intl. Board for Plant Genetics, Rome.

Grubben, G.J.H. 1980. Cultivation methods and growth analysis of vegetable amaranth, with special reference to South-Benin. Proc. 2nd Amaranth Conf., Kutztown, Pa.

Haas, P.W. and A. Schauer, 1985. Summary of 1984 amaranth time of planting research trial. RRC/NC85/11. Rodale Press, Emmaus, Pa.

Huang, P.C. 1980. A study of the taxonomy of the edible amaranth: An investigation of amaranth both of botanical and horticultural characteristics. Proc. 2nd Amaranth Conf., Kutztown, Pa.

Igbokwe, P.E., S.C. Tiwari, J.B. Collins, J.B. Tartt, and L.C. Russell. 1988. Amaranth-A potential crop for southwestern Mississippi. Res. Rpt. 13 No. 10. Mississippi Agr. and For. Expt. Sta., Mississippi State Univ., Mississippi State.

Makus, D.J. 1984. Evaluation of amaranth as a potential greens crop in the mid-south. HortScience 19:881883.

Makus, D.J. and D.R. Davis. 1984. A mid-summer crop for fresh greens or canning-vegetable amaranth. Ark. Farm Res. May-June.

Makus, D.J. 1989. Aluminum accumulation in vegetable amaranth grown in a soil with adjusted $\mathrm{pH}$ values. HortScience 24:460-463.

Makus, D.J. 1990a. Composition and nutritive value of vegetable amaranth as affected by stage of growth, environment and method of preparation. Proc. 4th Amaranth Symp. Minneapolis, 23-25 Aug. 1990.

Makus, D.J. 1990b. Applied nitrogen affects vegetable and grain amaranth seed yield and quality. Proc. 4 th Amaranth Symp. Minneapolis, 23-25 Aug. 1990.

Myers, R.L. 1996. Amaranth: New crop opportunity, p. 207-220. In: J. Janick (ed.). Progress in new crops. ASHS Press, Alexandria, Va.

National Research Council (NRC). 1984. Amaranth: modern prospects for an ancient crop. Natl. Academy Press, Washington, D.C.

Putnam, D.H. 1990. Agronomic practices for grain amaranth. Proc. 4th Amaranth Symp., Minneapolis, 23-25 Aug. 1990.

Rangarajan, A. and J. Kelly. 1994. Iron availability from Amaranthus species. Legacy 7:1-4.

SAS Institute. 1988. SAS users' guide: Statistics, Ver. 6.03. SAS Inst., Cary, N.C.

Sawhney, S., R.K. Kohli, and N. Sawhney. 1980. Photoperiodic studies on Amaranthus. Indian J. Plant Physiol. 23:103-111.

Sealy, K.L., E.L. McWilliams, J. Novak, F. Fong, and C.M. Kenerly. 1990. Vegetable amaranth: Cultivar selection for summer production in the south, $p$. 396-398. In: J. Janick and J.E. Simon (eds.). Advances in new crops. Timber Press, Portland, Ore.

Segura-Nieto, M., A.P. Barba de la Rosa, and O. ParedesLopez. 1994. Biochemistry of amaranth proteins, p. 75-106. In: O. Paredes-Lopez (ed.). Amaranth biology, chemistry, and technology. CRCPress, Boca Raton, Fla.

Stallknecht, G.E and J.R. Schultz-Schaeffer. 1993. Amaranth rediscovered, p. 211-221. In: J. Janick and J.E. Simon (eds.). New crops. Wiley, New York.

Teutonico, R.A. and D. Knorr. 1985. Amaranth: Composition, properties, and applications of a rediscovered food crop. Food Technol. 39:49-60.

Webb, D.M., C.W. Smith, and J. Schulz-Schaeffer. 1987. Amaranth seedling emergence as affected by seedling depth and temperature on a thermogradient plate. Agron. J. 79:23-26. 